\title{
SHOPPING MOTIVATIONS OF GENERATION Z CUSTOMERS FOR DIFFERENT RETAILER TYPES AND SHOPPING COMPANION
}

\author{
U. Yozgat*, C. Arıker \\ İstanbul Kültür University, Ataköy Yerleşkesi, E-5 Karayolu Üzeri, 34156 Bakırköy İstanbul \\ *u.yozgat@iku.edu.tr
}

\begin{abstract}
This study is into the changes in shopping motivations of Generation $Z$ customers. The first objective is to reveal whether or not Generation $Z$ customers visit different retailer types with different shopping motivations. The study also aims to investigate whether or not shopping motivations of Generation $Z$ customers change by existence of a shopping companion. The results showed that Generation $Z$ customers visit different retailer types with different shopping motivations. Additionally, they act with different shopping motivations when they visit retailers alone or with a shopping companion. This research has some practical implications. It creates an opportunity to determine right retailing strategies for different retailer types. It also helps to sales assistants about how to approach Generation $\mathrm{Z}$ customers when they visit retailers alone or with a shopping companion.
\end{abstract}

Keywords: Generation Z, Shopping Motivations, Retailer Types, Shopping Companion

\section{INTRODUCTION}

As studies in the retailing literature showed, customers may have various shopping motivations when they visit retailers. The shopping motivations are divided into two main groups as utilitarian and hedonic. Although there are plenty of studies dealing with shopping motivations, lack of researches investigating whether or not customers visit different retailer types with different shopping motivations is felt. There are many independent studies examining shopping motivations of customers when they visit fashion retailers (Kang \& Park-Poaps, 2010), restaurants (Arnold \& Reynolds, 2003; Babin et al., 2005; El-Adly \& Eid, 2015) and shopping malls (Pookulangara \& Knight, 2013; Rahmawati \& Do, 2015; Teller et al., 2008; ). However, studies comparing shopping motivations of customers visiting different types of retailers can be found rarely (Davis \& Dyer, 2012; Terblanche \& Boshoff, 2004). Similarly, no studies dealt with the question whether or not customers have different shopping motivations when they visit retailers alone or with a shopping companion. Additionally, studies handling shopping motivations of the Generation $\mathrm{Z}$ customers are very limited. Most of those studies focus on shopping motivations of young customers within the frame of shopping mall visits (Can et al., 2016; Štulec et al., 2016), online shopping (Ibrahim et al., 2016; Swarnakar et al., 2016; Wagner et al., 2016) and mobile shopping (Xu \& Wohn, 2016). On the other hand, studies to develop an understanding for the shopping behavior of Generation $Z$ customers would be very precious. Because Generation $Z$ people are current customers of retailers and their spending are expected to increase continuously in the near future.

For this reason, this study aims to reveal whether or not Generation $\mathrm{Z}$ customers visit different retailer types with different shopping motivations. The study also aims to investigate whether or not shopping motivations of Generation $\mathrm{Z}$ customers change by existence of a shopping companion.

The research is believed to be significant both for researchers and practitioners. First of all, it contributes to the literature by examining one of the fundamental issues of retailing, shopping motivations within the frame of Generation Z. Secondly, it has an exhaustive scope due to dealing with differences in shopping motivations for different retailer types. Previous studies approach shopping motivations as a general construct or within the frame of a specific retailer type. On the other hand, they ignore possibility of visiting different retailer types with different shopping motivations. Discovery of different shopping motivations for different retailer types would present a practical benefit to retailers. In this way, they can develop proper strategies that match with the dominant 
shopping motivations of customers to visit their specific stores. Finally, there is no study that has questioned whether or not shopping motivations differ by visiting retailers alone or with a shopping companion. Developing an understanding about the effect of shopping companion on shopping motivations can help sales assistants about on which shopping motivations they can build their face-toface communication.

\section{LITERATURE REVIEW}

In the literature, shopping motivations of customers are grouped into two main clusters as utilitarian and hedonic (Babin et al., 1994). When customers act with utilitarian shopping motivations, they are interested in achievement of ordinary shopping objectives such as purchasing right product, at the right price, from the right place and with minimum effort whereas customers want to feel excitement, experience adventure and enjoy store atmospherics when they focus on hedonic motivations (Shukla \& Babin, 2013; Teller et al., 2008). Babin et al. (1994; 2005) associated utilitarian shopping motivations with seeking just for the planned products, finding the targeted product easily and completing the shopping task within a short time (Babin et al., 1994). In the literature, utilitarian shopping motivations are generally summarized under dimensions of choice motivation (Davis \& Dyer, 2012; Terblanche \& Boshoff, 2004), price motivation (Mathwick et al., 2002) and time motivation (Davis \& Dyer, 2012; El-Adly \& Eid, 2015). Arnold and Reynolds (2003) classified hedonic shopping motivations as adventure shopping, gratification shopping, role shopping, value shopping, social shopping and idea shopping (Arnold \& Reynolds, 2003). The authors defined adventure shopping as "shopping for stimulation, adventure and the feeling of being in another world"; gratification shopping as "shopping for stress relief, shopping to alleviate a negative mood, shopping as a special treat to oneself"; role shopping as "the enjoyment that shoppers derive from shopping for others, the influence that this activity has on the shoppers' feelings and moods, the excitement and intrinsic joy felt by shoppers when finding the perfect gift for others"; value shopping as "shopping for sales, looking for discounts and hunting for bargains"; social shopping as "the enjoyment of shopping with friends and family, socializing and bonding with others while shopping" and idea shopping as "shopping to keep up with trends and new fashions, to see new products and innovations" (Arnold \& Reynolds, 2003). Terblanche and Boshoff (2004) mentioned another hedonic dimension which is related to the emotions that are created by physical attractiveness of the retail setting (Baker \& Haytko, 2004; Terblanche \& Boshoff, 2004). Davis and Dyer (2012) called this dimension as aesthetics motivation in their work that compares shopping motivations to visit mass merchandisers and department stores (Amatulli \& Guido, 2012; Chebat et al., 2012; Davis \& Dyer, 2012). Rintamaki et al. (2006) defined another dimension called as social status motivation and defined it as a consumer's feeling of social acceptability and approval as a result of shopping at certain retail stores.

There are many independent studies examining shopping motivations of customers. For instance, some studies focus on shopping motivations of customers who visit fashion retailers (Kang \& Park-Poaps, 2010). Other groups of studies examine shopping motivations for service retailers like restaurants (Arnold \& Reynolds, 2003; Babin et al., 2005). Researches investigating shopping motivations of customers to visit shopping malls can also be found (El-Adly \& Eid, 2015; Pookulangara \& Knight, 2013; Rahmawati \& Do, 2015; Teller et al., 2008). However, studies that include a simultaneous comparison of shopping motivations of customers visiting different types of retailers can be found rarely (Davis \& Dyer, 2012; Terblanche \& Boshoff, 2004). As known, retailers can be classified into different types by various factors such as product variety and assortment, level of service, level of prices and organization. Retailers can also be classified as merchandise retailers and service retailers. Another classification distinguishes brick-and-mortar and click-and-mortar retailers. Naturally, different types of retailers require different strategies from the standpoint of marketers (Davis \& Dyer, 2012). Retailers need to take their customers' shopping motivations into consideration in order to develop proper strategies to reach their target markets. Customers may also visit different types of retailers with different kinds of utilitarian and/or hedonic shopping motivations. Shopping motivations of the same customer for different types of retailers such as fashion retailers, restaurants, cosmetic retailers, supermarkets, toy stores can be different which in turn requires, from the point of retailer, different approaches to retailer brand positioning. Retailing managers can make decision on the main frame of retailer brand positioning when shopping motivations of target customers are determined. Customers may have different types of shopping motivations when they visit different types of 
retailers. Although many studies regarding shopping motivation can be found in the literature, research with more holistic approach to compare shopping motivations for different retailer types are missing. Additionally, studies that are interested in the shopping motivations of the latest customer generation, Generation $Z$ are very limited. Most of those studies focus on shopping motivations of young customers within the frame of shopping mall visits (Can et al., 2016; Śtulec et al., 2016), online shopping (Ibrahim et al., 2016; Swarnakar et al., 2016; Wagner et al., 2016) and mobile shopping. On the other hand, studies to develop an understanding for the shopping behavior of Generation $Z$ customers would be very precious. Because Generation $\mathrm{Z}$ people are current customers of retailers and their spending are expected to increase continuously in the near future. For these reasons, we hypothesize:

H1: Shopping motivations of Generation Z customers are not equal when they visit different retailer types.

According to the literature on the effect of shopping companion, visiting retailers alone or with friends and/or family members have some effects on the whole shopping process. Decisions such as which retailers will be preferred, how much time and money will be spent in the preferred retailers and the total shopping experience may differ by visiting the stores alone or with a shopping companion (Argo et al., 2005; Borges et al., 2010; Chebat et al., 2012), especially, young customers can perceive shopping as a socialization opportunity, prefer visiting retailers with their friends and affect each other (Baker \& Haytko, 2004). The shopping motivations may differ by the existence of shopping companion. On the other hand, no study handling the effect of existence of shopping companion on the shopping motivations can be found in the literature. If the shopping motivations change by visiting the retailers alone or with a shopping companion, sales assistants have to approach customers differently. Thus, we propose the following hypothesis:

H2: Shopping motivations of Generation $Z$ customers are not equal when they visit retailers alone or with a shopping companion.

\section{METHODOLOGY}

\section{Sampling}

Main population of this research was determined as the first members of Generation $\mathrm{Z}$ who born between 1995 and 2000 (Berkup, 2014; Ziemba \& Eisenbardt, 2014; Levickaite, 2010; Malone, 2007; Williams \& Page, 2011; Tulgan, 2013; Veiga \& Alípio, 2013). They are the current customers of retailers and their spending are expected to increase in the future. For this reason, it is important to understand which different retailers they visit with which different shopping motivations. Managers of retailers can determine proper marketing strategies accordingly. Sampling frame was limited to university students born within this interval, since it is difficult to reach all of the first members of Generation Z. 322 university students were reached through convenience sampling method.

\section{Data Collection}

A survey including Shopping Motivation Scale was used to collect data. Shopping Motivation Scale includes six hedonic sub-dimensions: self-gratification motivation, value motivation, social motivation, idea motivation (Arnold \& Reynolds, 2003; El-Adly \& Eid, 2015), social status motivation (Davis \& Dyer, 2012; Rintamaki et al., 2006) and aesthetics motivation (Davis \& Dyer, 2012; Terblanche \& Boshoff, 2004). The scale includes three utilitarian sub-dimensions: choice motivation (Terblanche \& Boshoff, 2004), price motivation (Mathwick et al., 2002) and time motivation (El-Adly \& Eid, 2015). Sub-dimensions that are proper to answer for all the retailer types were selected. These sub-dimensions were used in Davis and Dyer (2012) work in which shopping motivations for mass and department stores were compared (Amatulli \& Guido, 2012; Chebat et al., 2012; Davis \& Dyer, 2012). The scale consisted of 33 items.

First of all, the participants are required to write a retailer brand name they visited and satisfied. Then, they answered the Shopping Motivation Scale items for this retailer. Finally, they were asked to answer the question of "With whom did you visit this retailer?". Number of usable survey was 293.

\section{Data Analysis}

The retailers that were visited by the participants are classified and coded by their types (Table 1 ). 
Table 1. Retailer types

\begin{tabular}{|c|c|c|}
\hline Retailer Type & f & \% \\
\hline Fashion Retailers & 85 & 29.0 \\
\hline Shopping Mall Restaurants & 95 & 32.4 \\
\hline Cafes & 48 & 16.4 \\
\hline Luxury Fashion Retailers & 28 & 9.6 \\
\hline Luxury Restaurants & 28 & 9.6 \\
\hline Other & 9 & 3.0 \\
\hline Total & 293 & 100.0 \\
\hline
\end{tabular}

Exploratory Factor Analysis and ANOVA Test were used to analyse the survey data after testing scale reliability. Initial Cronbach Alpha value of Shopping Motivation Scale was 0.861. The result of reliability analysis showed that if the item of "The prices of the product(s) I purchased from this retailer are too high, given the quality of the merchandise" was deleted, the value of Cronbach Alpha could be increased. Accordingly, final Cronbach Alpha value was 0.871 which is acceptable for the social sciences researches (Hair et al., 1998; Ozdamar, 2004).

After reliability analysis, Exploratory Factor Analysis with varimax rotation was conducted to find sub-dimensions of Shopping Motivation Scale. KMO Sampling Adequacy was 0.859 ve Barlett's Test of Sphericity was significant. The resulting eight factors are "Value Motivation", "Social Motivation", "Aesthetic Motivation", "Idea Motivation", "Choice Motivation", "Gratification Motivation", Time Motivation" and "Price Motivation". The factor structure is compatible with the literature. Factor reliabilities fluctuate between 0.937 and 0.602 . Factors explained $66.7 \%$ of the total variance. 3 items ("The music was beautiful.", "I enjoyed socializing with others when I went to this place" and "I visited this place with my friends or family to socialize") exhibiting factor loadings below 0.50 were eliminated. 3 items ("I visited this place to experience new products", "In this place, shopping with others was a bonding experience." and "I went shopping here with my friends or family to socialize.") with cross-loadings were also eliminated. The Cronbach Alpha value of the final scale including 26 items was 0.872 .

ANOVA Test was implemented to reveal whether Generation $\mathrm{Z}$ customers visit different retailer types with different shopping motivations. Results showed that "Value Motivation", "Social Motivation", "Aesthetic Motivation", "Idea Motivation", "Gratification Motivation", "Time Motivation" and "Price Motivation" of Generation $\mathrm{Z}$ customers differ by the type of retailers $(\mathrm{p}=0.05)$. On the other hand, "Choice Motivation" does not change by the retailer type. For this reason, H1 is accepted substantially. Post Hoc Comparisons are given in Table 2.

Table 2. Post hoc comparisons of shopping motivation versus retailer type**

\begin{tabular}{|c|c|c|c|c|c|}
\hline \multirow{2}{*}{\begin{tabular}{|c|}
$\begin{array}{c}\text { Dependent } \\
\text { Variable }\end{array}$ \\
$\begin{array}{c}\text { Type of Shopping } \\
\text { Motivation }\end{array}$ \\
\end{tabular}} & \multicolumn{2}{|c|}{ Retailer Type } & \multirow{2}{*}{$\begin{array}{c}\text { Mean } \\
\text { Difference (I- } \\
\text { J) }\end{array}$} & \multirow{2}{*}{$\begin{array}{l}\text { Std. } \\
\text { Error }\end{array}$} & \multirow{2}{*}{ Sig. } \\
\hline & $\begin{array}{l}\text { Retailer } \\
\text { Type (I) }\end{array}$ & $\begin{array}{l}\text { Retailer } \\
\text { Type (J) }\end{array}$ & & & \\
\hline \multirow[t]{2}{*}{ Value Motivation } & \multirow{2}{*}{$\begin{array}{l}\text { Fashion } \\
\text { Retailers }\end{array}$} & $\begin{array}{c}\text { Shopping Mall } \\
\text { Restaurants }\end{array}$ & $1,42536^{*}$ & .17047 & .000 \\
\hline & & Cafes &, $89351^{*}$ & .20574 & .000 \\
\hline
\end{tabular}


The Turkish Online Journal of Design, Art and Communication - TOJDAC

ISSN: 2146-5193, September 2018 Special Edition, p.759-768

\begin{tabular}{|c|c|c|c|c|c|}
\hline & & & & & \\
\hline & & Luxury Restaurants & $1,88533^{*}$ & .24796 & .000 \\
\hline & \multirow{2}{*}{$\begin{array}{l}\text { Shopping } \\
\text { Mall } \\
\text { Restaurants }\end{array}$} & Cafes &,$- 53185^{*}$ & .20092 & .009 \\
\hline & & Luxury Fashion Retailers & $-1,02218^{*}$ & .24398 & .000 \\
\hline & Cafes & Luxury Restaurants & ,99182* & .26980 & .000 \\
\hline & $\begin{array}{l}\text { Luxury } \\
\text { Fashion } \\
\text { Retailers }\end{array}$ & Luxury Restaurants & $1,48214^{*}$ & .30323 & .000 \\
\hline \multirow{3}{*}{$\begin{array}{l}\text { Social Status } \\
\text { Motivation }\end{array}$} & \multirow{3}{*}{$\begin{array}{c}\text { Luxury } \\
\text { Restaurants }\end{array}$} & $\begin{array}{l}\text { Shopping Mall } \\
\text { Restaurants }\end{array}$ &,$- 50461^{*}$ & .20947 & .017 \\
\hline & & Cafes &,$- 56771^{*}$ & .23164 & .015 \\
\hline & & Luxury Fashion Retailers &,$- 58929^{*}$ & .26034 & .024 \\
\hline \multirow{4}{*}{$\begin{array}{l}\text { Aesthetic } \\
\text { Motivation }\end{array}$} & \multirow{4}{*}{$\begin{array}{l}\text { Fashion } \\
\text { Retailers }\end{array}$} & $\begin{array}{c}\text { Shopping Mall } \\
\text { Restaurants }\end{array}$ &,$- 41750^{*}$ & .09675 & .000 \\
\hline & & Cafes &,$- 35210^{*}$ & .11676 & .003 \\
\hline & & Luxury Fashion Retailers &,$- 37070^{*}$ & .14072 & .009 \\
\hline & & Luxury Restaurants &,$- 33498^{*}$ & .14072 & .018 \\
\hline \multirow[t]{6}{*}{ Idea Motivation } & \multirow{3}{*}{$\begin{array}{l}\text { Fashion } \\
\text { Retailers }\end{array}$} & $\begin{array}{l}\text { Shopping Mall } \\
\text { Restaurants }\end{array}$ & $1,08455^{*}$ & .14261 & .000 \\
\hline & & Cafes & ,98184* & .17211 & .000 \\
\hline & & Luxury Restaurants & $1,33204^{*}$ & .20743 & .000 \\
\hline & \multirow{3}{*}{$\begin{array}{l}\text { Luxury } \\
\text { Fashion } \\
\text { Retailers }\end{array}$} & $\begin{array}{l}\text { Shopping Mall } \\
\text { Restaurants }\end{array}$ & $1,08584^{*}$ & .20410 & .000 \\
\hline & & Cafes & ,98313* & .22570 & .000 \\
\hline & & Luxury Restaurants & $1,33333^{*}$ & .25367 & .000 \\
\hline \multirow{4}{*}{$\begin{array}{l}\text { Self-Gratification } \\
\text { Motivation }\end{array}$} & \multirow{4}{*}{$\begin{array}{l}\text { Fashion } \\
\text { Retailers }\end{array}$} & $\begin{array}{l}\text { Shopping Mall } \\
\text { Restaurants }\end{array}$ &,$- 57666^{*}$ & .11350 & .000 \\
\hline & & Cafes &,$- 62561^{*}$ & .13684 & .000 \\
\hline & & Luxury Fashion Retailers &,$- 40418^{*}$ & .16481 & .015 \\
\hline & & Luxury Restaurants &,$- 38275^{*}$ & .16481 & .021 \\
\hline \multirow[t]{4}{*}{ Time Motivation } & $\begin{array}{l}\text { Shopping } \\
\text { Mall }\end{array}$ & Luxury Restaurants & ,39154* & .19279 & .043 \\
\hline & \multirow[t]{3}{*}{ Cafes } & Fashion Retailers & ,49034* & .16257 & .003 \\
\hline & & Luxury Fashion Retailers &, $67708^{*}$ & .21319 & .002 \\
\hline & & Luxury Restaurants & ,69494* & .21319 & .001 \\
\hline Price Motivation & & Fashion Retailers &,$- 73480^{*}$ & .18472 & .000 \\
\hline
\end{tabular}


The Turkish Online Journal of Design, Art and Communication - TOJDAC

ISSN: 2146-5193, September 2018 Special Edition, p.759-768

\begin{tabular}{|l|c|c|c|c|c|}
\cline { 3 - 5 } & $\begin{array}{c}\text { Luxury } \\
\text { Fashion } \\
\text { Retailers }\end{array}$ & $\begin{array}{c}\text { Shopping Mall } \\
\text { Restaurants }\end{array}$ &,$- 61541^{*}$ & .18175 & .001 \\
\cline { 3 - 6 } & & Cafes &,$- 79914^{*}$ & .20177 & .000 \\
\cline { 3 - 6 } & $\begin{array}{c}\text { Luxury } \\
\text { Restaurants }\end{array}$ & $\begin{array}{c}\text { Shophion Retailers } \\
\text { Restaurants }\end{array}$ &,$- 63956^{*}$ & .18472 & .001 \\
\cline { 3 - 6 } & &,$- 52018^{*}$ & .18175 & .005 \\
\cline { 3 - 6 } & Cafes &,$- 70390^{*}$ & .20177 & .001 \\
\hline
\end{tabular}

*The mean difference is significant at the 0.05 level.

**Table includes just the significant differences.

ANOVA Test was implemented to reveal whether the shopping motivations of Generation $\mathrm{Z}$ customers differ when they visit retailers alone or with their friends. Results showed that "Value Motivation" and "Idea Motivation" of Generation Z customers differ by the shopping companion $(p=0.05)$. Both of the "Value Motivation" and "Idea Motivation" are higher when Generation Z customers visit the retailers alone. On the other hand, other shopping motivations do not change by the retailer type. For this reason, $\mathrm{H} 2$ is accepted partially. Post Hoc Comparisons are given in Table 3.

Table 3. Post hoc comparisons of shopping motivation versus shopping companion**

\begin{tabular}{|c|c|c|c|c|c|}
\hline Dependent Variable & \multicolumn{2}{|c|}{ Shopping Companion } & \multirow[b]{2}{*}{$\begin{array}{c}\text { Mean } \\
\text { Difference } \\
\text { (I-J) }\end{array}$} & \multirow[b]{2}{*}{$\begin{array}{l}\text { Std. } \\
\text { Error }\end{array}$} & \multirow[b]{2}{*}{ Sig. } \\
\hline $\begin{array}{c}\text { Type of } \\
\text { Shopping } \\
\text { Motivation }\end{array}$ & $\begin{array}{c}\text { Shopping } \\
\text { Companion (I) }\end{array}$ & $\begin{array}{c}\text { Shopping } \\
\text { Companion (J) }\end{array}$ & & & \\
\hline \multirow{2}{*}{ Value Motivation } & \multirow{2}{*}{ Alone } & With friends & $.87155^{*}$ & .22490 & .002 \\
\hline & & With family members & .71340 & .30706 & .147 \\
\hline \multirow{2}{*}{$\begin{array}{c}\text { Idea } \\
\text { Motivation }\end{array}$} & \multirow{2}{*}{ Alone } & With friends & $.82901^{*}$ & .18458 & .000 \\
\hline & & With family members & .67818 & .25200 & .067 \\
\hline
\end{tabular}

*The mean difference is significant at the 0.05 level.

**Table includes just the significant differences.

\section{RESULTS AND DISCUSSION}

The results of this study can be helpful to develop some suggestions for the managers of different retailer types. The results showed that "Value Motivation" of Generation Z customers is higher when they visit fashion retailers and luxury fashion retailers in comparison to restaurants. Accordingly, Generation Z customers seem like acting with "Value Motivation" when they select fashion retailers to visit. This result is also compatible with the results of Lee et al. (2015). Therefore, the managers of fashion retailers can be suggested to develop sales promotion campaigns in order to attract these young customers. On the other hand, Generation Z customers do not behave with "Value Motivation" when they visit luxury restaurants. As a result, the managers of luxury restaurants are suggested to focus on other motivation types such as aesthetic, idea, self-gratification and social-status when they determine marketing strategies targeting these customers. According to the findings, shopping from luxury fashion retailers is matched with "Social Status Motivation", a result that is compatible with the literature (Amatulli \& Guido, 2012; Jalil et al., 2016; Liu et al., 2013). For this reason, the managers of luxury fashion retailers can be proposed to develop a positioning based on the concepts of high price and social status. On the other hand, the managers should not forget that Generation Z customers also seek discounts and promotions when they visit luxury fashion retailers. In other words, "Value Motivation" also affects these customers when they shop from luxury fashion retailers. The results 
show that Generation $\mathrm{Z}$ customers are influenced by aesthetic elements of the stores more when they visit shopping mall restaurants, cafes, luxury fashion retailers and luxury restaurants in comparison to fashion retailers. In the literature, the effect of aesthetic benefits on consumers' restaurant preferences are largely mentioned (Jensen \& Hansen, 2007; Pettersson \& Fjellström, 2007). Therefore, the managers of these stores are recommended to emphasize on aesthetics elements of store design such as decoration, attractive product displays, music, scent etc. and provide a good experience to young customers. As known, "Idea Motivation" is especially listed as one of the most important motivation factors that direct customers to fashion retailers (Cano, 2016; Dale, 2017; Falode et al., 2016; Parker et al., 2016). Our findings support this opinion, Generation Z customers act with more "Idea Motivation" when they visit fashion retailers and luxury fashion retailers in comparison to shopping mall restaurants, cafes and luxury restaurants. For this reason, the managers of fashion retailers and luxury fashion retailers are suggested to follow the newest trends and present creative and innovative designs to these customers. Sales assistants should make idea oriented presentations when they communicate with Generation Z. The findings suggest that Generation $\mathrm{Z}$ customers have higher "Self-Gratification Motivation" when they visit shopping mall restaurants, cafes, luxury fashion retailers and luxury restaurants in comparison to fashion retailers. In other words, the first Generation $\mathrm{Z}$ customers focus on their individual happiness when they make preferences for these retailers. As a result, the managers of these retailers are recommended to focus on individual happiness of their customers from Generation $\mathrm{Z}$ and make them feel special. Socialization, one of the hedonic shopping motivations (Y1lmaz, \& Gültekin, 2016; Arnold \& Reynolds, 2003) is not an important motivation for Generation $\mathrm{Z}$ customers as the results of Factor Analysis show that items regarding socialization was eliminated because of the low factor loadings. When the behaviours of young people observed, it can be seen that they are interested in their mobile phones most of the time when they visit retailers with their friends. Generation $\mathrm{Z}$ may have a different understanding of socialization as highlighted in the literature (Levickaite, 2010; Turner, 2015). This finding shows us a need to develop a new scale to measure this new socialization understanding. In other words, items in the scale of Arnold and Reynolds (2003) may not proper to measure the socialization motivation of the new generation. Socialization motivation may also give its place to new shopping motivations such as proper store environment to use technological devices, availability of charging devices, store design centered on technology and so on. The results also show that Generation Z customers have higher "Social Status Motivation" when they visit shopping mall restaurants and cafes in comparison to luxury restaurants. For this reason, the managers of shopping mall restaurants and cafes can be recommended to develop a positioning for their brands based on social status although "Price Motivation" of Generation Z customers is also high for these types of retailers. Accordingly, these young customers visit luxury restaurants with other motivations. The findings show that Generation Z customers act with more "Time Motivation" and "Price Motivation" when they visit shopping mall restaurants and cafes in comparison to other retailer types. For this reason, managers of these stores have to remember that features like being open until late hours, being open most of the time and accessible prices are important factors affecting the preferences of the first customers of Generation $Z$ as well as being a status symbol. To summarize, "Value Motivation" and "Idea Motivation" are dominant when Generation Z customers visit fashion retailers and luxury fashion retailers. "Self-Gratification Motivation" and "Aesthetic Motivation" are the primary shopping motivations that direct their preferences for shopping mall restaurants, cafes and luxury restaurants. "Social Status Motivation", "Price Motivation" and "Time Motivation" influence these customers' preferences for shopping mall restaurants and cafes. The results hold that Generation $\mathrm{Z}$ customers have higher "Value Motivation" and "Idea Motivation" when they visit the retailers alone in comparison to with friends. Therefore, sales assistants can be suggested to emphasize on discounts and sales promotions when these customers visit their stores alone. In other words, they should avoid from communicating discounts and sales promotions when the Generation $\mathrm{Z}$ customers visit these stores with their friends. Similarly, sales assistants should take into consideration that Generation Z customers may be more open to new ideas and innovations when they visit these stores alone in comparison to visiting with a shopping companion.

\section{CONCLUSION}

The research is believed to be significant both for researchers and practitioners. First of all, it contributes to the literature by examining one of the fundamental issues of retailing, shopping motivations, within the frame of Generation Z. Secondly, it has an exhaustive scope due to dealing 
with differences in shopping motivations for different retailer types. Previous studies approach shopping motivations as a general construct or within the frame of a specific retailer type. On the other hand, they ignore possibility of visiting different retailer types with different shopping motivations. Discovery of different shopping motivations for different retailer types would present a practical benefit to retailers. In this way, they can develop proper strategies that match with the dominant shopping motivations of customers to visit their specific stores. Finally, there is no study that has questioned whether or not shopping motivations differ by visiting retailers alone or with a shopping companion. Developing an understanding about the effect of shopping companion on shopping motivations can help sales assistants about on which shopping motivations they can build their face-toface communication.

This study has some limitations. First of all, the type of retailers are limited to fashion retailers, luxury fashion retailers, shopping mall restaurants, cafes and luxury restaurants. Therefore, caution is required when the results are generalized for other type of retailers. New researches are needed to understand the shopping motivations of these customers when they visit other type of retailers such as cosmetics, toy, consumer electronics and so on. Secondly, the sample covers only university students. The shopping motivations of other groups representing Generation $\mathrm{Z}$ customers may be different. Future research is suggested to show the shopping motivations of Generation $Z$ customers from other socioeconomic groups. Finally, the findings support the idea that Generation $Z$ people have a different socialization understanding and items in current scales may not be proper to measure how this new socialization motivates them during shopping. For this reason, future studies are suggested to focus on developing new scale items proper to measure Generation Z's socialization motivation, how a need to develop a new scale to measure socialization understanding of Generation Z, may not proper to measure the socialization motivation of the new generation. Future work is suggested to focus on this issue.

\section{REFERENCES}

Amatulli, C., \& Guido, G. (2012). Externalised vs. internalised consumption of luxury goods: Propositions and implications for luxury retail marketing. International Review of Retail, Distribution and Consumer Research, 22(2), 189-207.

Argo, J., Dahl, D., \& Manchanda, R. (2005). The influence of a mere social presence in a retail context. Journal of Consumer Research, 32(2), 207-212.

Arnold, M. J., \& Reynolds, K. E. (2003). Hedonic shopping motivations. Journal of Retailing, 79(2), 77-95.

Babin, B. J., Darden, W. R., \& Griffin, M. (1994). Work and/or fun: Measuring hedonic and utilitarian shopping value. Journal of Consumer Research, 20(4), 644-656.

Babin, B. J., Lee, Y. K., Kim, E. J., \& Griffin, M. (2005). Modeling consumer satisfaction and word-ofmouth: Restaurant patronage in Korea. Journal of Services Marketing, 19(3), 133-139.

Baker, J., \& Haytko, D. L. (2004). It's all at the mall: Exploring adolescent girls' experiences. Journal of Retailing, 80(1), 67-83.

Berkup, S. B. (2014). Working with generations $X$ and $Y$ in generation $Z$ period: Management of different generations in business life. Mediterranean Journal of Social Sciences, 5(19), 218-229.

Borges, A., Babin, B, \& Chebat, J. C. (2010). Does a companion always enhance the shopping experience? Journal of Retailing and Consumer Services, 17(4), 294-299.

Can, G. F., Can, G. F., Kurtulmusoglu, F. B., Kurtulmusoglu, F. B., Atalay, K. D., Atalay, \& K. D. (2016). A case study on shopping malls attributes for young consumers. Young Consumers, 17(3), 274-292.

Cano, M. B. (2016). The role of cross-country differences in international fashion retailing: Ecommerce development in Spain and the UK. In Handbook of Research on Global Fashion Management and Merchandising. IGI Global, pp. 622-648.

Chebat, J. C., Haj-Salem, N., \& Oliveira, S. (2012). Three psychological processes explaining the impact of the shopping pal on mall shoppers. In 12th International Research Conference in Service Management, pp. 1-20. 
Dale, H. S. (2017). Flagships and visual merchandising: Effect of retail store type on shopper response to visual merchandising in the fashion clothing industry. https://ir.canterbury.ac.nz/handle/ 10092/13535.

Davis, L. Y., \& Dyer, B. (2012). Consumers' value perceptions across retail outlets: Shopping at mass merchandisers and department stores. International Review of Retail, Distribution and Consumer Research, 22(2), 115-142.

El-Adly, M. I., \& Eid, R. (2015). Measuring the perceived value of malls in a non-western context: The case of the UAE. International Journal of Retail and Distribution Management, 43(9), 849-869.

Falode, B. O., Amubode, A. A., Adegunwa, M. O., \& Ogunduyile, S. R. (2016). Online and offline shopping motivation of apparel consumers in Ibadan Metropolis, Nigeria. International Journal of Marketing Studies, 8(1), 150-160.

Hair, J. F., Anderson, R. E., Tatham, R. L., \& Black, W. C. (1998). Multivariate data analysis. Prentice Hall.

Ibrahim, N., Zakaria, Z., \& Mansor, N. (2016). Role of trust in mediating the predictors of internet shopping behavior among university students. Journal of Applied Environmental Biology Science, 6(1S), 62-69.

Jalil, A., Usman, A., \& Zakar, R. (2016). When sellers' behaviour goes bad: Linking customer discrimination and customer's visible characteristics. Anthropological Notebooks, 22(1), 77-94.

Jensen, Ø., \& Hansen, K. V. (2007). Consumer values among restaurant customers. International Journal of Hospitality Management, 26(3), 603-622.

Kang, J., \& Park-Poaps, H. (2010). Hedonic and utilitarian shopping motivations of fashion leadership. Journal of Fashion Marketing and Management, 14(2), 312-328.

Lee, S., Kim, \& K. P., Lee, S. (2015). Identifying predictors of compulsive hoarding tendencies in young adult consumers. Fashion Business, 19(3), 43-58.

Levickaite, R. (2010). Generations X, Y, Z: How social networks form the concept of the world without borders (the case of Lithuania). Limes, 3(2): 170-183.

Ozdamar, K. (2004). Statistical data analysis with package programs. Kaan Bookstore.

Liu, X., Burns, A. C., \& Hou, Y. (2013). Comparing online and in-store shopping behavior towards luxury goods. International Journal of Retail and Distribution Management, 41(11/12), 885-900.

Malone, K. (2007). The bubble-wrap generation: Children growing up in walled gardens. Environmental Education Research, 13(4), 513-527.

Mathwick, C., Malhotra, N. K., \& Rigdon, E. (2002). The effect of dynamic retail experiences on experiential perceptions of value: An internet and catalog comparison. Journal of Retailing, 78(1), $51-60$.

Parker, C. J., Parker, C. J., Wang, H., \& Wang, H. (2016). Examining hedonic and utilitarian motivations for m-commerce fashion retail app engagement. Journal of Fashion Marketing and Management: An International Journal, 20(4), 487-506.

Pettersson, A., \& Fjellström, C. (2007). Restaurants as friends of the family: Functions of restaurant visits in everyday life. Journal of Foodservice, 18(6), 207-217.

Pookulangara, S., \& Knight, D. K. (2013). Indian consumers' mall patronage intentions: Impacts of shopping motivations, subjective norms, materialism, and self-efficacy. Journal of Global Fashion Marketing, 4(1), 20-32.

Rahmawati, R., \& Do, B. R. (2015). Shopping motivation on purchase intention: Can loyalty program and corporate image enhance such relationship? Asia-Pacific Management and Business Application, 2(3), 154-169.

Rintamaki, T., Kanto, A., Kuusela, H., \& Spence, M. T. (2006). Decomposing the value of department store shopping into utilitarian, hedonic and social dimensions: Evidence from Finland. International Journal of Retail and Distribution Management, 34(1), 6-24.

Shukla, P., \& Babin, B. J. (2013). Effects of consumer psychographics and store characteristics in influencing shopping value and store switching. Journal of Consumer Behaviour, 12(3), 194-203.

Štulec, I., Petljak, K., \& Maslać, I. (2016). Mixing the right retail tenant mix: Assessing young consumers shopping centre patronage. In Colloquium on European Research in Retailing, pp. 284-286.

Swarnakar, P., Kumar, A., \& Kumar, S. (2016). Why generation y prefers online shopping: A study of young customers of India. International Journal of Business Forecasting and Marketing Intelligence, 2(3), 215-232. 
Teller, C., Reutterer, T., \& Schnedlitz, P. (2008). Hedonic and utilitarian shopper types in evolved and created retail agglomerations. International Review of Retail, Distribution and Consumer Research, 18(3), 283-309.

Terblanche, N., \& Boshoff, C. (2004), The in-store shopping experience: A comparative study of supermarket and clothing store customers. South African Journal of Business Management, 35(4), $1-10$.

Tulgan, B. (2013). Meet generation Z: The second generation within the giant "millenial" cohort. http://www.rainmakerthinking.com/assets/uploads/2013/10/Gen-Z-Whitepaper.pdf.

Turner, A. (2015). Generation Z: Technology and social interest. Journal of Individual Psychology, 71(2), 103-113.

Veiga, N., \& Alípio, R. (2013). Fatores determinantes do interesse em questões ambientais entre consumidores da geração Z. Revista Global Manager, 13(1), 108-127.

Wagner, G., Schramm-Klein, H., \& Schu, M. (2016). Determinants and moderators of consumers' cross-border online shopping intentions. Marketing ZFP, 38(4), 214-227.

Williams, K. C., \& Page, R. A. (2011). Marketing to the generations. Journal of Behavioral Studies in Business, 3(1), 37-53.

$X u, Y$., \& Wohn, D. Y. (2016). Understanding incentives and deterrents of mobile shopping. In Conference 2016 Proceedings, pp. 1-6.

Yllmaz, G., \& Gültekin, S. (2016). Consumers and tourists' restaurant selections. In Global Issues and Trends in Tourism. St. Kliment Ohridski University Press, pp. 217-230.

Ziemba, E., \& Eisenbardt, M. (2014). Prosumers' eagerness for knowledge sharing with enterprises-a Polish study. Online Journal of Applied Knowledge Management, 2(1), 40-58. 